\title{
Antibacterial effect of metallic nanoparticles on Streptococcus mutans bacterial strain with or without diode laser $(970 \mathrm{~nm})$
}

\author{
Doaa M. Sadony ${ }^{* *}$ and Hanan El-sayed Abozaid ${ }^{2}$
}

\begin{abstract}
Background: The main etiological agent for dental caries is Streptococcus mutans bacterial strain. Recently, metallic nanoparticles and diode laser have been introduced as a new method in bacterial decontamination. Nanoparticles have very small particles size that has greater surface area and exert their antimicrobial effect by interacting with the negatively charged bacterial cell wall, while lasers have become increasingly popular in dentistry due to their multiple uses, and one such important application is tooth disinfection.
\end{abstract}

Objective: Present study was conducted to evaluate antimicrobial efficacy of silver (AgNPs) and gold nanoparticles (AuNPs) with and without diode laser $(970 \mathrm{~nm}, 15 \mathrm{~Hz}, 100 \mathrm{~mJ}, 2 \mathrm{~W}$, each cycle was $10 \mathrm{~s}$ and repeated 6 times with intervals of $5 \mathrm{~s}$ for each sample) irradiation against experimentally inoculated $\mathrm{S}$. mutans bacteria in the samples.

Material and methods: Thirty freshly a traumatically extracted premolars human tooth were collected, and cylindrical cavity in crowns with $4 \mathrm{~mm}$ diameter and $5 \mathrm{~mm}$ depth was prepared and inoculated with $\mathrm{S}$. mutans for $24 \mathrm{~h}$. The tooth were randomlly divided into equal expermintal groups ( 6 each): group 1 , positive control group by $S$. mutans bacterial strain; group 2, irrigation with silver nanoparticles (AgNPs) for 3 min; group 3, irrigation with gold nanoparticles (AuNPs) for $3 \mathrm{~min}$; group 4, $3 \mathrm{ml}$ AgNPs + irradiation with diode laser for $60 \mathrm{~s}$; and group 5, $3 \mathrm{ml}$ AuNPs + irradiation with diode for $60 \mathrm{~s}$. The specimens were collected from the teeth sample, and colony-forming units (CFU's) were observed by counting the bacteria colony on plates.

Results: A significant difference was found among all the groups in comparison to the control group $(p<0.05)$. The greatest reduction in CFU's was observed in combination of AgNPs with diode laser group.

Conclusions: The NPs in combination with diode laser irradiation has the potential to be used as dentine disinfectant.

Keywords: Antibacterial effect, Gold, Silver, Nanoparticles, Diode lasers

\section{Introduction}

The main objective of carious removal is to eliminate the carious tissues and micro-organisms causing tooth decay and tretment failure, so the clinical success of a restoration depends mainly on the removal of infected dentin. Incomplete removal of all micro-organisms in residual tissue may occur in the traditional caries removal, where the bacteria and micro-organisms present in the

\footnotetext{
* Correspondence: doaamohamedsadony@yahoo.com

${ }^{1}$ Restorative and Dental Materials Department, National Research Centre, Dokki, Giza, Egypt

Full list of author information is available at the end of the article
}

smear layer,contaminated surface before restoration, in dentinal tubules, and at dentino-enamel junction may invade into the cavity by invasion via marginal gap between a teeth and a restoration. Many studies have demonstrated that the bacteria remain in the dentin due to any of the above infection sources and could maintain their activities for a long time (Hadley et al. 2000).

Dental caries remain the most widespread disease in the world; about $95 \%$ of populations are affected by it in different ages (Vitale et al. 2011). Since the discovery of the $S$. mutans as the main source for dental caries, the attention by studies has focused on this bacteria as a 
target to prevent carious disease by using antimicrobial agents or vaccines (Banerjee et al. 2000; Wilson 1994). The use of some antimicrobial agents and fluoride have resulted in the decrease in the spread or occurrence of dental caries (Hadley et al. 2000), but they reported that antibiotics and chemical bactericides sometimes disturb the bacterial flora of the oral cavity and develop multidrug resistance to certain bacterial strains (Wilson 1994; Concannon et al. 2003). Also, in some cases, the use of fluoride is not very effective (Ying et al. 2017). So there is a need for using an agent who does not generate resistance and presents a good bactericidal effect.

Nanoparticles have been used in dentistry to provide enhanced mechanical properties and antibacterial effects. These materials contribute to remarkable antimicrobial properties and demonstrate comparable physical properties when compared with conventional materials because of their small size and increased surface area (Abou Neel et al. 2015).

They exert their antimicrobial effect by interacting with the negatively charged bacterial cell wall. Various nanoparticles have been tested against the microbes for their antimicrobial efficacy, e.g., silver (Ag), gold (Au), and Zinc $(\mathrm{Zn})$, and out of these, silver nanoparticles have been found to be the most effective (Samiei et al. 2016). Silver nanoparticles have a great antibacterial effect on several numbers and types of bacteria and microorganisms; its bactericidal effect depends on the size and the shape of the particles (Pal et al. 2007; Kim et al. 2007). Nanomaterials became efficient that can replace conventional irrigation materials in most applications of dental science. As a result of the very small size and higher surface/volume ratio of nanomaterials, they have a high number of active atoms at their outer surfaces for bactericidal effect (Ameer et al. 2009). For example, gold nanoparticles (AuNPs) are widely used in different medical applications mainly in gene therapy and for diagnosis; it has lower toxicity properties compared to other metallic nanomaterials (Shamaila et al. 2016).

Lasers have become increasingly popular in dentistry due to their multiple uses, and one such important application is disinfection of the root canal system. Evidence suggests that laser can pentrate to depths greater than $400 \mu \mathrm{m}$ inside the dentinal tubules and cause the killing of bacteria in these greater depths (Siavash et al. 2013). Lasers apart from causing bactericidal effect also cause occlusion of the dentinal tubules and thereby closing all the avenues of bacterial reinfection. The antibacterial effect of laser on the target cell, tissue, or organism may be photochemical, photo-thermal, photo-ablative, or photo-mechanical. The soft lasers induce photochemical changes only while hard lasers produce all of the abovementioned effects depending on the laser type and the operating condition (Wilson 1994). Different laser types have antibacterial effects on different microorganisms. For example, diode and erbium lasers are able to produce a bactericidal effect and eliminate the residual caries efficiently with no thermal effect on residual sound tooth structure (Adriana et al. 2014; Yan et al. 2015).

\section{Material and methods \\ Teeth preparation}

A total of 30 freshly sound atraumatically extracted premolars were selected from patients within the age group $20-40$ years. They were scaled to remove any debris and calculus with a dental scaler (Sonicflex 2000, KaVo Co., Biberbach, Germany) under running water to remove any debris or calculus deposits. All teeth were stored in $48{ }^{\circ} \mathrm{C}$ distilled water containing $0.2 \%$ thymol to prevent microbial growth until use. Crowns of the teeth were cut horizontally with a water-cooled diamond disk to obtain flat dentinal surfaces under water coolant to expose the mid-coronal dentin. The teeth were embedded in a cylindrical polyvinyal tube, poured with autopolymerizing acrylic resin, and each specimen received oval cavity by \#245 burs (4 $\mathrm{mm}$ in diameter, $5 \mathrm{~mm}$ in depth) in the middle one third of the occlusal surface leaving $2 \mathrm{~mm}$ from each surface. The specimens of all groups were adapted in the stainless steel boxes which were covered with aluminum foil and placed in autoclave for $15 \mathrm{~min}$ at $121{ }^{\circ} \mathrm{C}$ (Vianna et al. 2004).

\section{Preparation of gold nanoparticles (AuNPS)}

It was prepared by citrate reduction of gold (III) chloride trihydrate (Turkevich et al. 1951). Before the reduction process, all glassware were cleaned in aqua regain (3 part $\mathrm{HCl}$ to 1 part $\mathrm{HNO}_{3}$ ), rinsed with deionized $\mathrm{H}_{2} \mathrm{O}$ and dried. An aqueous solution of gold (III) chloride trihydrate $\left(\mathrm{HAuCl} 43 \mathrm{H}_{2} \mathrm{O}\right)$ from Sigma-Aldrich, USA $(100 \mathrm{ml}$, $1 \mathrm{mM}$ ), was brought to boiling condition and stirred continuously; then, a solution of $38.8 \mathrm{ml}$ sodium citrate tribasic dehydrate $\left(\mathrm{C}_{6} \mathrm{H}_{5} \mathrm{Na}_{3} \mathrm{O}_{7} 2 \mathrm{H}_{2} \mathrm{O}\right)$ was added quickly at one time, resulting in a change in solution color from pale yellow to black deep red which indicates the formation of gold nanoparticles $(10-13 \mathrm{~nm})$. The prepared AuNPs were diluted in deionized water where the morphology and quality of NPs were investigated using UV-Vis spectro-photometry (T80+, PG Instruments, UK) and transmission electron microscopy (TEM, JEOL JEM-2100) equipped with GATAN CCD Camera (Orius SC200) (Kushwaha et al. 2018). The absorption spectrum of AuNPs was capped with citrate in aqueous medium, recorded in the wavelength $400-700 \mathrm{~nm}$. The spectrum is characterized by a Gaussian distribution indicating the formation of spherical particles that are well dispersed in water solvent with high uniformity. The 
characteristic plasmon band was detected at $520 \mathrm{~nm}$ which corresponds to particle sizes $13 \mathrm{~nm}$ in diameters.

\section{Preparation of spherical silver nanoparticles $\left(\mathrm{AgNP}_{\mathrm{s}}\right)$}

A mixture of $0.08 \mathrm{~g}$ trisodium citrate and $0.2 \mathrm{~g}$ PVP (polyvinylpyrolidone) has been dissolved in $10 \mathrm{ml}$ water with stirring, and $0.75 \mathrm{ml}$ of $0.01 \mathrm{M} \mathrm{AaNO}{ }_{3}$ has been added to the reaction mixture. Yellow color appears upon the addition, which indicates the formation of spherical silver nanoparticles $(10-13 \mathrm{~nm})$. The prepared AgNPs were diluted in deionized water where the morphology and quality of NPs were investigated using a sensitive method of $\mathrm{AgNP}_{\mathrm{S}}$ (Métrauxet Gand Mirkin 2005; Amin et al. 2009), While the absorption spectrum of AgNPs was capped with citrate in aqueous medium, recorded in the wavelength range of $250-700 \mathrm{~nm}$, the spectrum is characterized by a Gaussian distribution indicating the formation of spherical particles that are well dispersed in water solvent with high uniformity. The characteristic plasmon band was detected at $410 \mathrm{~nm}$ which corresponds to particle sizes $13 \mathrm{~nm}$ in diameters.

\section{Microbiological procedures}

Clinical isolates of $S$. mutans were used as the test microorganisms. A single colony of $S$. mutans was inoculated in $5 \mathrm{ml}$ brain heart infusion broth (BHI-broth) in the screw-capped vial and incubated at $37^{\circ} \mathrm{C}$ for $24 \mathrm{~h}$. After that, $0.5 \mathrm{ml}$ of bacterial suspension was added to $0.5 \mathrm{ml} \mathrm{BHI-broth}$ in the screw-capped vial giving a final concentration of $4 \times 107 \mathrm{CFU} / \mathrm{ml}$. Before inoculation, the coronal cavities were dried by absorbent endodontic paper points. Then, each cavity for each group was inoculated with $10 \mu \mathrm{l}$ of a bacterial suspension containing 4 . $\times 105 \mathrm{CFU}$ by micropipette and incubated at $37^{\circ} \mathrm{C}$ for 24h (Lansdown 2006).

\section{Experimental groups}

The specimens were inoculated with bacteria and divided into five groups $(n=6)$ :

Group 1 (control group): inoculated with bacterial suspension containing $4 \times 10^{5} \mathrm{CFU}$ by micropipette and incubated at $37^{\circ} \mathrm{C}$ for $24 \mathrm{~h}$ with bacterial strain.

Group 2 (AgNPs): root canals were irrigated with $3 \mathrm{ml}$ of AgNPs solution having a concentration of $100 \mathrm{ppm}$ and an average particle size of $13 \mathrm{~nm}$, using a 30-gauge needle attached to a 3-ml syringe. The solution was allowed to remain in contact with the cavity for $3 \mathrm{~min}$ and then aspirated using the same needle.

Group 3 (AuNPs): root canals were irrigated with $3 \mathrm{ml}$ of AuNPs solution having a concentration of $100 \mathrm{ppm}$ and an average particle size of $13 \mathrm{~nm}$, using a 30-gauge needle attached to a 3-ml syringe. The solution was allowed to remain in contact with the cavity for $3 \mathrm{~min}$ and then aspirated using the same needle.
Group 4 (AgNPs + diode laser): root canals were irrigated with $3 \mathrm{ml}$ of AgNPs solution having a concentration of $100 \mathrm{ppm}$ and an average particle size of $13 \mathrm{~nm}$, using a 30-gauge needle attached to a 3-ml syringe followed by simultaneous irradiation of the canal with diode laser delivered by $200 \mu \mathrm{m}$ fiber tip, activated at 15 $\mathrm{Hz}, 100 \mathrm{~mJ}$, and $2 \mathrm{~W}$ power setting in circular motion for $60 \mathrm{~s}$ with circular motion in straight angle from depth of cavity till outer surface of crown. The duration of each laser cycle was $10 \mathrm{~s}$ and repeated 6 times with intervals of $5 \mathrm{~s}$ for each sample.

Group 5 (AuNPs + diode laser): root canals were irrigated with $3 \mathrm{ml}$ of AuNPs solution having a concentration of $100 \mathrm{ppm}$ and an average particle size of $13 \mathrm{~nm}$, using a 30-gauge needle attached to a 3-ml syringe followed by simultaneous irradiation of the canal with diode laser delivered by $200 \mu \mathrm{m}$ fiber tip, activated at 15 $\mathrm{Hz}, 100 \mathrm{~mJ}$, and $2 \mathrm{~W}$ power setting for $60 \mathrm{~s}$ with circular motion. The duration of each laser cycle was $10 \mathrm{~s}$ and repeated 6 times with intervals of $5 \mathrm{~s}$ for each sample.

\section{Incubation and microbial sampling of experimental groups}

The sterile paper point no. \#40 was used to collect the transfer fluid and enamel, dentinal chips. Then, it was transferred into a test tube containing $10 \mathrm{ml}$ of sterile saline and vortexed for $20 \mathrm{~s}$ using vortex shaker. Fifty microliters of the vortexed saline was applied to the agar plates and incubated at $37^{\circ} \mathrm{C}$ for $48 \mathrm{~h}$. The colonyforming units per milliliter for each plate was calculated using a bacterial colony counter (Colony Star, Funke Gerber Product, Gebr Liebisch, Germany) (Sohrabi et al. 2016; Sieuwerts et al. 2008).

\section{Results}

The mean and standard deviation values were calculated for each group in each test. Viable counts of antibacterial activity were transformed to their $\log 10$ values. Data were explored for normality using Kolmogorov-Smirnov and Shapiro-Wilk tests and showed parametric (normal) distribution. One-way ANOVA followed by Tukey's test was used to compare between more than two groups in non-related samples. The significance level was set at $p$ $\leq 0.05$. Statistical analysis was performed with $\mathrm{IBM}^{\circ}$ SPSS $^{\oplus}$ Statistics Version 20 for Windows.

Antibacterial activity results are shown in Table 1):

There was a statistically significant difference between groups $1,2,3,4$, and 5 , where $p \leq 0.05$.

A statistically significant difference was found between group 1 and each of groups 2, 3, 4, and 5 where $p<0.001$.

Also, a statistically significant difference was found between group 2 and each of groups 3, 4, and 5 where $p<$ 0.001 . 
Table 1 The mean and standard deviation (SD) values of $\mathrm{LOG}^{10}$ for bacterial count of different groups

\begin{tabular}{lll}
\hline Variables & Antibacterial activity & \\
\cline { 2 - 3 } & Mean & SD \\
\hline G1 (control) & 4.41 & 0.01 \\
G2 (Ag) & 3.88 & 0.05 \\
G3 (Au) & 4.16 & 0.02 \\
G4 (Ag + laser) & 2.94 & 0.03 \\
G5 (AU + laser) & 3.65 & 0.04 \\
$p$ value & $<0.001^{*}$ &
\end{tabular}

ns non-significant $(p>0.05)$

*Significant $(p<0.05)$

A statistically significant difference was found between group 3 and each of groups 4 and 5 where $p<0.001$.

The highest mean value of bacterial count was found in group 1 , followed by group 3 , group 2 , and group 5 , while the least mean value of bacterial count was found in group 4.

\section{Discussion}

In oral micro-organisms, $S$. mutans has been identified as a plaque-forming bacterium which has the ability to produce dental caries in humans (Parirokh et al. 2007). The main objective of caries removal is to remove the infected and necrotic tissues and microorganisms that cause inflammation and treatment failure. The ordinary caries treatment not always removes all of the microorganisms in the residual tissues (Jew et al. 2017), as the bacteria are capable to diffuse into the dentinal tubules up to a depth of $1 \mathrm{~mm}$, while the chemical disinfectants penetrate up to $130 \mu \mathrm{m}$ inside the dentine (Gutknecht and Franzen 2004). This difference in depth of penetration between the invading bacteria and the disinfectant solution is responsible for the recurrent caries in many of the cases which can be observed in the conventional dental procedures.

Nanoparticles are newer class of antimicrobials that have positively charged high surface area that interact with the negatively charged bacterial cell wall and exert their antimicrobial effect. To the best of our knowledge, antimicrobial efficacy of silver nanoparticles has been reported in the literature by various authors but their combined effect when used with simultaneous diode laser irradiation has not been reported and it will be very interesting to know the antimicrobial efficacy of silver and gold nanoparticles when used with simultaneous diode laser irradiation as lasers can penetrate to dentinal depths of more than $1000 \mu \mathrm{m}$ (Stojicic et al. 2013). A culture-dependent approach used in this study is considered to be one of the most accurate methods of detecting the tested bacteria, when the samples are taken immediately after the antimicrobial treatment as in Mohammadi and Abbott (Mohammadi and Abbott 2009).

Among various lasers available, diode laser is probably one of the most effective lasers for the disinfection of $S$. mutans (Moritz et al. 1999; Lee 2006). In study by Prażmo et al. 2017), a reduction of bacteria colonies was found when diode laser was used alone, which is in disagreement with the present study; the individual effects of diode laser irradiation were observed, but combination of laser with nanoparticles was evaluated with significantly better results obtained. It attributed to the deep penetration effects of laser followed by antimicrobial effects of nanoparticles.

Simultaneous irradiation of diode laser and AgNPs irrigation showed significantly better results followed by group AuNPs + diode laser in terms of colony-forming units in comparison to other groups, as in a study by Rahimi et al. (Rahimi et al. 2012); the results obtained can be attributed to the deep dentinal tubule penetration by diode laser followed by high surface charge characteristics of silver nanoparticles, i.e., antimicrobial effects of nanoparticles, as in agreement with our result that the group AgNPs + diode laser showed less bacterial account followed by the group AuNPs + diode laser. This result is in agreement with Korshed et al. (Korshed et al. 2016) who reported that silver NPs generated by hypicosecal laser have strong antibacterial effect against both Gram-positive and Gram-negative bacteria and also in agreement with Zainab et al. (Zainab et al. 2015) and Juan et al. (Juan et al. 2015).

The present study was conducted with the aim of evaluating the effect of silver and gold nanoparticle irrigation alone and followed by simultaneous diode laser irradiation in eliminating S. mutans. In the current study group (AgNPs + laser) showed significant reduction in $S$. mutans colonies in comparison with the control group, and these findings are followed with the results reported with the group AuNPs + laser, followed by group AgNPs, and then group AuNPs against S. mutans which is in agreement with Afkhami et al. who use Enterococcus faecalis bacterial strain with different type of irrigation methods (Moritz et al. 1999).

In the present study, significantly different results were obtained when diode laser irradiation was used in combination with silver and gold nanoparticles as in agreement with Hernández-Sierra et al. (Hernández-Sierra et al. 2008), which higher antimicrobial efficacy of SNPs was found against Streptococcus mutans in comparison with $\mathrm{AU}$ and $\mathrm{ZnO}$ nanoparticles. Silver nanoparticles have high effect which depends on superficial contact, inhibits enzymatic systems of the respiratory chain, and alters DNA synthesis. Many studies reported that gold has a weak antimicrobial effect against many microorganisms (Elsome et al. 1996; Jasim 2018). 
In this study, the irradiation technique was as cycles, each cycle consisted of $10 \mathrm{~s}$; six cycles of irradiation inside the infected cavities were used in this study. This technique was applied because bacterial growth had been formed inside the infected cavities which required more than one cycle of laser irradiation to reach the deeper layer and disrupt it. Using one cycle may probably result in partial disruption of the bacterial layer, and the high bacterial reduction was observed in all cases by repeating laser treatment with a high-power diode laser which is in agreement with Kushwaha et al. (Kushwaha et al. 2018).

\section{Conclusion}

Application of diode lasers in combination with metallic nanoparticles is a successful method for the reduction of microbial colonies of $S$. mutans in comparison with other experimental groups.

\section{Abbreviation}

AgNPs: Silver nanoparticles; AuNPs: Gold nanoparticles; CFU's: Colonyforming units; NPs: Nanoparticles; S. mutans: Streptococcus mutans bacterial strain

\section{Acknowledgements}

All authors are very grateful to the National Research Centre.

\section{Authors' contributions}

DMS conceived of the study, carried out the dental studies, participated in its design and coordination, performed the statistical analysis, helped to revise the manuscript, and helped to draft the manuscript. HA carried out the bacterial studies and participated in the sequence alignment and drafted the manuscript. All authors read and approved the final manuscript.

\section{Funding}

No fund available.

\section{Availability of data and materials}

The datasets used and analyzed during the current study are available from the corresponding author on reasonable request.

\section{Ethics approval and consent to participate}

Not applicable.

\section{Consent for publication}

Not applicable.

\section{Competing interests}

The authors declare that they have no competing interests.

\section{Author details}

${ }^{1}$ Restorative and Dental Materials Department, National Research Centre, Dokki, Giza, Egypt. 'Lecturer of Clinical Pathology, Faculty of Medicine, Helwan University, Cairo, Egypt.

Received: 16 November 2019 Accepted: 23 December 2019 Published online: 31 December 2019

\section{References}

Abou Neel E, Bozec L, Perez R, Kim H, Knowles J (2015) Nanotechnology in dentistry: Prevention, diagnosis, and therapy. Int J Nanomedicine 10:63716394

Adriana B, Cynthia S, Patrícia A, Sergio B, Denise M (2014) Laser technology for caries removal. Contemp Approach Dent Caries 15:291-312
Ameer A, Faheem A, Nishat A, Chaman M, Naqvi A (2009) One step synthesis of gold nanoparticles and their antibacterial activities against E. coli (ATCC 25922 strain). Int J Theoretical Appl Sci 1:1-4

Amin R, Mohamed M, Ramadan M, Verwanger T, Krammer B (2009) Rapid and sensitive microplate assay for screening the effect of silver and gold nanoparticles on bacteria. Nanomedicine 4:637-643

Banerjee A, Watson F, Kidd A (2000) Dentine caries excavation: a review of current clinical techniques. Br Dent J 188:476-482

Concannon S, Crowe T, Abercrombie J, Molina C, Hou P, Sukumaran D (2003) Susceptibility of oral bacteria to an antimicrobial decapeptide. J Med Microbiol 52:1083-1093

Elsome A, Hamilton-Miller J, Brumfitt W, Noble W (1996) Anti- microbial activities in vitro and in vivo of transition element complexes containing gold (I) and osmium (VI). J Antimicrob Chemother 37:911-918

Gutknecht N, Franzen R (2004) Bactericidal effect of a 980-nm diode laser in the root canal wall dentin of bovine teeth. J Clin Laser Med Surg 22:9-13

Hadley J, Young D, Eversole L, Gornbern J (2000) A laser-powered hydrokinetic system for caries removal and cavity preparation. J Am Dent Assoc 131:777-785

Hernández-Sierra J, Ruiz F, Pena D, Martínez-Gutiérrez F, Martínez A, Guillén A (2008) The antimicrobial sensitivity of Streptococcus mutans to nanoparticles of silver, zinc oxide, and gold. Nanomed Nanotechnol Biol Med 4:237-240

Jasim TM (2018) Antibacterial effect of diode laser and silver nanoparticles against biofilm bacteria. J Glob Harmatechnol 10:509-515

Jew J, Chan K, Darling C, Fried D (2017) Selective removal of natural caries lesions from dentin and tooth occlusal surfaces using a diode-pumped Er:YAG laser. Proc SPIE Int Soc Opt Eng 28:1-10

Juan C, Gabriel A, Fidel M, Norma V, Nuria P, Nereyda N, Zaragoza V, CabralRomero CC (2015) Antibacterial and anti bio film activities of the photo thermal therapy using cold nanorods against seven different bacterial strain. J Nanomater 7:1-7

Kim J, Kuk E, Yu K, Kim J, Park S, Lee H, Kim S, Park Y, Park Y, Hwang C, Kim Y, Lee $Y$, Jeong D, Cho M (2007) Antimicrobial effects of silver nanoparticles. Nanomedicine 3:95-101

Korshed P, Li L, Liu Z, Wang T (2016) The molecular mechanisim of the antibacterial effect of picosecond laser generated silver nanoparticle and their toxicity to human cell. PLoS One 11:1-23

Kushwaha V, Yadav R, Tikku A, Chandra A, Verma P, Gupta P, Shakya V (2018) Comparative evaluation of antibacterial effect of nanoparticles and lasers against endodontic microbiota: an in vitro study. J Clin Exp Dent 10:1155-1160

Lansdown A (2006) Silver in health care: antimicrobial effects and safety in use. Curr Probl Dermatol 33:17-34

Lee B (2006) LinY, Chia J, Hsieh T, Chen M, Lin C, Lan W. Bactericidal effects of diode laser on Streptococcus mutants after irradiation through different thickness of dentin. Lasers Surg Med 38:62-69

Métrauxet Gand Mirkin C (2005) Rapid thermal synthesis of silver nanoprisms with chemically tailorable thickness. Adv Mater 17:412-415

Mohammadi T, Abbott A (2009) The properties and applications of chlorhexidine in endodontics. Int Endod J 9:288-302

Moritz A, Schoop U, Goharkhay K, Jakolitsch S, Kluger W, Wer-nisch J (1999) The bactericidal effect of $\mathrm{Nd}$ : YAG, Ho: YAG, and Er: YAG laser irradiation in the root canal: an in vitro comparison. J Clin Laser Med Surg 17:161-164

Pal S, Tak Y, Song J (2007) Does the antibacterial activity of silver nanoparticles depend on the shape of the nanoparticle? A study of the Gram-negative bacterium Escherichia coli. Appl Environ Microbiol 73:1712-1720

Parirokh M, Eghbal M, Stowe S (2007) Effect of diode laser irradiation on root canal walls after smear layer removal. Iran Endod J 2:37-46

Prażmo E, Godlewska A, Sałkiewicz M, Mielczarek A (2017) Effects of 980 nm diode laser application protocols on the reduction of Enterococcus faecalis intracanal biofilm: an in vitro study. Dent Med Probl 54:333-338

Rahimi S, Shahi S, Gholizadeh S, Shakouie S, Rikhtegaran S, Soroush Barhaghi MH (2012) Bactericidal effects of Nd: YAG laser irradiation and sodium hypochlorite solution on Enterococcus faecalis biofilm. Photomed Laser Surg 30:637-641

Samiei M, Farjami A, Dizaj SM, Lotfipour F (2016) Nanoparticles for antimicrobial purposes in endodontics: a systematic review of in vitro studies. Mater Sci Eng C 58:1269-1278

Shamaila S, Zafar N, Riaz S, Sharif R, Nazir J, Naseem S (2016) Gold nanoparticles: an efficient antimicrobial agent against enteric bacterial human pathogen. J Nanomater 6:71

Siavash S, Parnian A, Elmira J, Amir A, Fatemeh P, Sahand R, Melina A (2013) Comparison of the effect of $\mathrm{Nd}: \mathrm{YAG}$ and diode lasers and photodynamic 
therapy on microleakage of class $V$ composite resin restorations. J Dent Res Dent Clin Dent Prospects 7:74-80

Sieuwerts S, De Bok F, Mols E, De Vos W, Hylckama V (2008) A simple and fast method for determining colony forming units. Lett Appl Microbiol 47:275-278

Sohrabi K, Sooratgar A, Zolfagharnasab K, Kharazifard M, Afkhami F (2016) Antibacterial activity of diode laser and sodium hypochlorite in Enterococcus Faecalis -contaminated root canals. Iran Endod J 11:8-12

Stojicic S, Amorim H, Shen Y, Haapasalo M (2013) Ex vivo killing of Enterococcus faecalis and mixed plaque bacteria in planktonic and biofilm culture by modified photoactivated disinfection. Int Endod J 46:649-659

Turkevich J, Stevenson P, Hillier J (1951) A study of the nucleation and growth processes in the synthesis of colloidal gold. Discuss Faraday Soc 11:55-75

Vianna M, Gomes B, Berber V, Zaia A, Ferraz C, de Souza-Filho F (2004) In vitro evaluation of the antimicrobial activity of chlorhexidine and sodium hypochlorite. Oral Surg Oral Med Oral Pathol Oral Radiol Endod 97:79-84

Vitale M, Zaffe D, Botticell D, Caprioglio C (2011) Diode laser irradiation and fluoride uptake in human teeth. Eur Arch Paediatr Dent 12:90-92

Wilson M (1994) Bactericidal effect of laser light and its potential use in the treatment of plaque-related diseases. Int Dent J 2:181-189

Yan R, Chan K, Tom H, Simon J, Darling C, Fried D (2015) Selective removal of dental caries with a diode-pumped Er:YAG laser. Proc SPIE Int Soc Opt Eng 24:1-16

Ying L, Bernd B, Li J, Wim C, Cor-Van L, Dong D (2017) Fluoride resistance in Streptococcus mutans: a mini review. J Oral Microbiol 9:1-9

Zainab A, Ziad T, Ayyad A (2015) Antimicrobial effect of silver nanoparticle produced by laser Ablation. Iraqi I Sci 56:2170-2186

\section{Publisher's Note}

Springer Nature remains neutral with regard to jurisdictional claims in published maps and institutional affiliations.

\section{Submit your manuscript to a SpringerOpen ${ }^{\circ}$ journal and benefit from:}

- Convenient online submission

- Rigorous peer review

- Open access: articles freely available online

- High visibility within the field

- Retaining the copyright to your article

Submit your next manuscript at $\boldsymbol{\nabla}$ springeropen.com 